\title{
PEMBERDAYAAN KADER DAN IBU BADUTA UNTUK MENCEGAH STUNTING DI DESA PILANGSARI KABUPATEN BOJONEGORO
}

\author{
Posyandu Cadres and Mother Empowerment to Prevent Stunting Prevalence \\ in Pilangsari Village, Bojnegoro Regency
}

\author{
Allyra Himawaty \\ Jurusan Ilmu Kesehatan Masyarakat, Fakultas Kesehatan Masyarakat, Universitas Airlangga, Jl. \\ Mulyorejo No.47 Surabaya, Jawa Timur, Indonesia
}

\begin{abstract}
Prevalence of stunting in Bojonegoro Regency is 34.9\%, higher than the national prevalence which $32.7 \%$ and is one of the districts that is the main focus of stunting eradication in East Java. Some of the factors indicated to be a contributing factor to the occurrence of stunting are cigarette consumption by parents, limited health information sources, non-varied feeding, absence of waste management and education and low parental income. Posyandu registration data for Pilangsari Village shows that there are at least 42 children out of 89 who are indicated as stunting. Interventions to prevent stunting must be started from the first 1000 days of life through specific interventions in the form of empowerment for posyandu cadres and poor women. The aim of this program is to increase the knowledge of baduta mothers and cadres to prevent stunting in Pilangsari Village. This empowerment program was carried out in the Field Work Practice activities of the Faculty of Public Health, Airlangga University for the period December 2019-January 2020 for 5 weeks, using an operational research design referring to PRECEED-PROCEED as a health education development framework. The sample of this research is the population of mothers with babies aged 0-2 years in Pilangsari Village as many as 46 respondents and 12 posyandu cadres in Pilangsari Village. The data collection technique used concurrent mixed methods with quantitative data obtained through a preliminary survey and the results of the pre-test \& post-test measured by the Wilcoxon signed rank test resulted in a significance increase in maternal knowledge of $0.005(p<0.05)$ with a confidence level of $\alpha=0$, 05. Qualitative data were obtained through observations and in-depth interviews. The variables measured in this study were the increase in maternal knowledge and the presence of mothers and cadres in the implementation of empowerment programs. This program is proven to be able to increase the knowledge of poor women related to the risk of stunting, provision of complementary foods to increase the provision of good nutrition for children, and increase the role of cadres as the front guard in implementing posyandu to prevent stunting
\end{abstract}

Keywords: community development, stunting, PRECEED-PROCEED

\begin{abstract}
Abstrak
Prevalensi stunting di Kabupaten Bojonegoro sebesar 34,9\% lebih tinggi dari prevalensi nasional sebesar 32,7\% dan merupakan salah satu kabupaten yang menjadi fokus utama pemberantasan stunting di Jawa Timur. Beberapa faktor yang terindikasi menjadi faktor penyebab terjadinya stunting adalah konsumsi rokok pada orangtua, sumber informasi kesehatan yang terbatas, pemberian makanan yang tidak bervariasi, tidak adanya pengelolaan sampah dan pendidikan serta pendapatan orangtua yang rendah. Data register posyandu Desa Pilangsari menunjukkan setidaknya tedapat 42 balita dari 89 balita yang terindikasi stunting. Intervensi untuk mencegah stunting harus dimulai sejak 1000 Hari Pertama Kehidupan melalui intervensi spesifik berwujud pemberdayaan kepada kader posyandu dan ibu baduta. Tujuan program ini adalah meningkatkan pengetahuan ibu baduta dan kader untuk mencegah terjadinya stunting di Desa Pilangsari. Program pemberdayaan ini dilaksanakan pada kegiatan Praktik Kerja Lapangan Fakultas Kesehatan Masyarakat Universitas Airlangga periode Desember 2019-Januari 2020 selama 5 minggu, menggunakan rancangan riset operasional mengacu pada PRECEED-PROCEED sebagai framework pengembangan pendidikan kesehatan. Sampel penelitian adalah populasi ibu dengan bayi usia 0-2 tahun di Desa Pilangsari sebanyak 46 responden dan 12 kader posyandu yang ada di Desa Pilangsari. Teknik pengumpulan data menggunakan concurrent mixed methods dengan data kuantitatif diperoleh melalui survei pendahuluan dan hasil pre-test $\&$ post test yang diukur melalui uji Wilcoxon
\end{abstract}


signed rank test menghasilkan signifikansi peningkatan pengetahuan ibu $0,005(\mathrm{p}<0,05)$ dengan tingkat kepercayaan $\alpha=0,05$. Data kualitatif diperoleh melalui hasil observasi dan indepth-interview. Variabel yang diukur dalam penelitian ini adalah peningkatan pengetahuan ibu dan tingkat kehadiran ibu dan kader dalam pelaksanaan program pemberdayaan. Program ini terbukti mampu meningkatkan pengetahuan ibu baduta terkait risiko stunting, pemberian MP-ASI untuk meningkatkan pemberian gizi yang baik bagi anak, serta meningkatkan peran kader sebagai garda terdepan pelaksanaan posyandu untuk mencegah kejadian stunting.

Kata kunci: pemberdayaan masyarakat, stunting, PRECEED-PROCEED

\section{PENDAHULUAN}

Stunting menurut World Health Organization (WHO) tahun 2005 adalah salah salah satu bentuk gizi kurang yang ditandai dengan tinggi badan menurut umur diukur dengan standar deviasi referensi. Stunting terjadi mulai janin masih dalam kandungan dan baru nampak saat anak berusia dua tahun. Menurut laporan Tim nasional Percepatan Penanggulangan Kemiskinan (TNP2K) stunting memiliki dampak yang panjang pada pertumbuhan negara. Produktivitas yang rendah akan mengakibatkan terhambatnya pertumbuhan ekonomi yang menyebabkan meningkatnya angka kemiskinan. Masalah stunting terjadi pada negara berkembang seperti Indonesia. Berdasarkan data dari Riskesdas Tahun 2018, Jawa Timur menempati provinsi dengan prevalensi stunting tertinggi melebihi angka prevalensi nasional yaitu sebesar 32,7\%. Kabupaten Bojonegoro merupakan salah satu kabupaten yang menjadi fokus utama pemberantasan stunting di Jawa Timur. (Wulandari and Kurniawan, 2019). Berdasarkan data dari Riskesdas 2018 angka prevalensi stunting di Kabupaten Bojonegoro sebesar 34,9\%.

Berdasarkan data screening posyandu Bulan Agustus 2019 pada 88 balita yang ada di 3 posyandu Desa Pilangsari, Kecamatan Kalitidu Kabupaten Bojonegoro, terdapat 42 balita dari 88 balita yang terindikasi stunting atau sebanyak $48 \%$ balita di tiga posyandu Desa Pilangsari. Data screening posyandu diolah oleh peneliti berdasarkan kriteria penetuan stunting Keputusan Menteri Kesehatan RI No. 1995 Tahun 2010. Penyebab stunting tidak hanya berasal dari pola makan saja, tetapi juga faktor lingkungan, pola asuh, pengetahuan, pendapatan keluarga, perilaku dan faktor lainnya. Stunting merupakan masalah multifaktor yang sebenarnya dapat dicegah (Budiastutik and Rahfiludin, 2019).

Mengingat kompleksnya faktor risiko terjadiya stunting, penguatan program 1000
Hari Pertama Kehidupan diharapkan dapat dikembangkan dan intervensi dilakukan secara berkesinambungan. (Rifiana and Agustina, 2018) Periode 1000 HPK merupakan waktu yang kritis dimana jika tidak dimanfaatkan dengan baik dapat menyebabkan kerusakan yang bersifat permanen (Nefy, Lipoeto and Edison, 2019). Perlunya ibu mendapatkan pendidikan yang berkualitas, memberikan asupan nutrien yang seimbang bagi anak serta dan upaya-upaya untuk meningkatkan derajat kesehatan anak (Hadi, Kumalasari and Kusumawati, 2019).

Data survei pendahuluan yang dilakukan kepada populasi ibu baduta di Desa Pilangsari menunjukkan sebanyak 65\% ibu memperoleh informasi kesehatan utama dari kader posyandu. Sehingga tingkat keaktifan dan pengetahuan kader posyandu sangat berpengaruh dalam membentuk pengetahuan ibu yang baik terkait stunting. Kader posyandu juga merupakan penggerak utama seluruh kegiatan yang dilaksanakan di posyandu. Keberadaan kader penting dan strategis, ketika pelayanan yang diberikan mendapat simpati dari masyarakat akan menimbulkan implikasi positif terhadap kepedulian dan partisipasi masyarakat. Salah satu permasalahan posyandu yang paling mendasar adalah rendahnya tingkat pengetahuan kader baik dari sisi akademis maupun teknis, karena itu untuk dapat memberikan pelayanan optimal di posyandu, diperlukan penyesuaian pengetahuan dan keterampilan kader, sehingga mampu melaksanakan kegiatan posyandu sesuai norma, standar, prosedur dan kriteria pegembangan posyandu. Kader perlu mendapatkan bekal pengetahuan dan keterampilan yang benar dalam melakukan penimbangan, pelayanan dan konseling atau penyuluhan gizi. (Pusat Promosi Kesehatan, 2012). Penguatan peran kader posyandu sebagai garda terdepan menjadi salah satu kunci utama penanganan stunting.

Intervensi yang diberikan perlu dilakukan secara efektif dan efisien berdasarkan faktor 
risiko yang terjadi di daerah tersebut. Kunci keberhasilan pelaksanaan pemberdayaan adalah perlunya kegiatan analisis dan perancangan program secara efisien. Untuk itu dalam pelaksanaan pemberdayaan ini menggunakan kerangka PRECEEDPROCEED sebagai alat untuk memberikan struktur yang komprehensif untuk menilai kesehatan dan kualitas kebutuhan dari ibu baduta dan kader posyandu. Adanya intervensi yang diberikan diharapkan dapat meningkatkan derajat kesehatan anak dan mencegah kejadian stunting melalui upaya-upaya pemberdayaan masyarakat.

\section{METODE PENELITIAN}

Penelitian ini dilaksanakan pada Praktik Kerja Lapangan Fakultas Kesehatan Masyarakat Universitas Airlangga periode Desember 2019Januari 2020 di Desa Pilangsari, Kecamatan Kalitidu, Kabupaten Bojonegoro. Waktu pemberdayaan terhitung 5 minggu sejak 27 Desember 2019 hingga 31 Januari 2020. Penelitian ini menggunakan rancangan riset operasional yaitu penelitian yang bertujuan memberikan solusi terhadap masalah operasional dalam pelaksanan program menggunakan teknik pengumpulan data concurrent mixed methods yang merupakan suatu pendekatan untuk mengkombinasikan bentuk kuantitatif dan kualitatif. Data kuantitaitf diperoleh melalui survei pendahuluan dan hasil pre-test \& post-test. Data kualitatif diperoleh melalui hasil observasi dan indepth-interview. Variabel yang diukur dalam penelitian ini adalah tingkat pengetahuan sebelum dan setelah pelaksanaan kegiatan melalui uji Wilcoxon signed rank test.

Survei pendahuluan dilakukan dengan penyebaran kuisioner yang dilaksanakan oleh tim Praktik Kerja Lapangan melalui wawancara yang dilakukan pada populasi ibu yang memiliki bayi berusia 0-2 tahun (ibu baduta) di Dusun Pilang dan Dusun Jambe Desa Pilangsari sebanyak 50 orang. Dari populasi sejumlah 50 ibu, didapatkan 46 responden karena 4 responden drop out. Selanjutnya kelompok Praktik kerja Lapangan melakukan observasi untuk mengamati aspek lingkungan yang meliputi air bersih dan jamban, pembuangan limbah, pengelolaan sampah dan rumah balita. In-depth interview dilakukan pada perwakilan dari masing-masing posyandu, yaitu 3 kader posyandu (Posyandu Mawar, Posyandu Bugenvil, Posyandu Anggrek) dan 1 bidan desa utuk memperoleh data yang lebih spesifik dan mendukung data hasil penyebaran kuisioner. Teori yang digunakan dalam penelitian ini mengacu pada framework PRECEDEPROCEED yang dapat membantu perencanaan suatu program kesehatan untuk menganalisis situasi dan program kesehatan secara efektif dan efisien. Data kuantitatif dan kualitatif yang telah dikumpulkan diolah dan dianalisis oleh peneliti menggunakan kerangka PRECEED-PROCEED yang terdiri dari : PRECEDE (Predisposing, Reinforcing, Enabling, Constructs in, Educational/ Ecological, Diagnosis, Evaluation) yang berfokus pada perencanaan program. Bagian yang kedua adalah PROCEED (Policy, Regulatory, Organizational, Constructs in, Educational, Enviromental, Development) merupakan proses implementasi dan evaluasi program intervensi (Green dan Kreuter, 2005).

Pemberdayaan dilaksanakan kepada 25 ibu dari 46 ibu yang datang pada saat kegiatan pemberdayaan dilaksanakan dan 12 kader posyandu Desa Pilangsari. Pemberdayaan berfokus pada pemberian informasi dan pelatihan bagi ibu juga diadakan pembekalan bagi kader posyandu dan pengaktifan kembali kegiatan posyandu yang mati suri, yaitu pengukuran tinggi badan dan berat badan anak secara berkala. Kegiatan yang dilakukan antara lain sosialisasi gizi seimbang dan kejadian stunting yang diberikan kepada ibu baduta yang dihadiri oleh perangkat desa, bidan desa, serta ibu baduta, demo masak MP-ASI, program tambahan berupa senam pagi untuk meningkatkan aktivitas fisik ibu, serta program revitalisasi kader posyandu dengan mengadakan sharing bersama para kader dan penambahan informasi bagi para kader.

\section{HASIL DAN PEMBAHASAN}

\section{Hasil Penelitian \\ Karakteristik Subyek Penelitian}

Karakteristik subyek penelitian diperoleh melalui survei pendahuluan pada 46 ibu baduta dengan analisis univariat.

Tabel 1. Distribusi Karakteristik Subyek Penelitian

\begin{tabular}{lll}
\hline Karakteristik & n & \% \\
\hline Pendidikan & & \\
SD & 21 & 46 \\
SMP & 15 & 32 \\
SMA/SLTA & 5 & 11 \\
Perguruan Tinggi & 5 & 11 \\
\hline
\end{tabular}


Tabel 1. Distribusi Karakteristik Subyek Penelitian (lanjutan)

\begin{tabular}{lcl}
\hline Karakteristik & n & \% \\
\hline Pendapatan orangtua & & \\
$<500.000$ & 5 & 11 \\
$500.000-1.000 .000$ & 21 & 45 \\
$1.000 .000-1.500 .000$ & 5 & 11 \\
$1.500 .000-2.000 .000$ & 0 & 0 \\
$2.000 .000-2.500 .000$ & 5 & 11 \\
$>2.500 .000$ & 10 & 22 \\
Orangtua Mengkonsumsi Rokok & \\
Ya & 37 & 80 \\
Tidak & 9 & 20 \\
Sumber Informasi Kesehatan Utama \\
Kader Posyandu & 29 & 65 \\
Puskesmas & 10 & 22 \\
Media massa & 5 & 11 \\
Koran/majalah & 2 & 5 \\
Variasi Pemberian Makanan & \\
Bervariasi & 11 & 24 \\
Tidak bervariasi & 35 & 76 \\
Pengelolaan sampah & \multicolumn{2}{l}{} \\
Ada & 3 & $7 \%$ \\
Tidak ada & 43 & $93 \%$ \\
\hline
\end{tabular}

Berdasarkan hasil survei pendahuluan, diperoleh karakterisik subyek penelitian yang merupakan faktor-faktor yang memiliki presentase tertinggi terindikasi menjadi faktor penyebab terjadinya stunting pada balita di Desa Pilangsari. Pendidikan ibu mayoritas merupakan lulusan SD yaitu sebanyak $46 \%$. Pendapatan orangtua juga mayoritas berada di bawah UMK Bojonegoro, yaitu sebesar Rp. 2.016.780,- yaitu sebanyak $67 \%$ memiliki pendapatan dibawah UMK. Sebanyak $80 \%$ orangtua mengkonsumsi rokok sehingga dapat mengganggu perkembangan pertumbuhan balita akibat paparan asap rokok. Mayoritas ibu mendapatkan informasi kesehatan melalui kader posyandu, yaitu sebesar $65 \%$. Serta permasalahan lain yang muncul berdasarkan data ini adalah variasi pemberian makanan yang diberikan oleh ibu sebanyak $76 \%$ tidak bervariasi dan tidak adanya sistem pengelolaan sampah, sebanyak $93 \%$ warga Desa Pilangsari membakar sampah rumah tangganya di depan rumah.

\section{Need Assessment (Phase 1-5)}

Hasil need assessment terhadap subyek pemberdayaan yang dilakukan dengan model PRECEDE. Berdasarkan metode yang telah dilakukan, didapatkan hasil sebagai berikut :

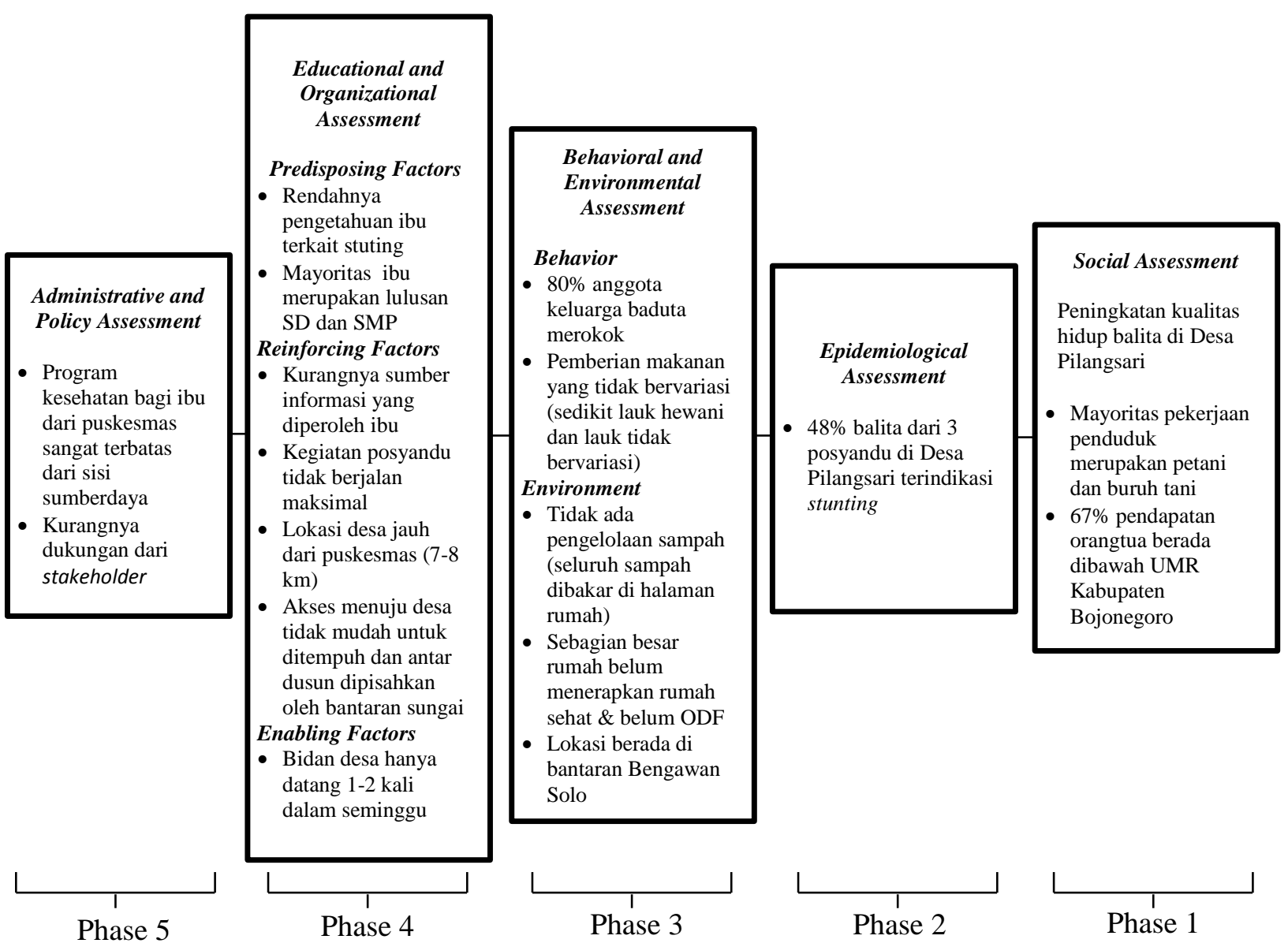

Gambar 1. Hasil Need Assessment menggunakan Kerangka PRECEED 
Tabel 2. Monitoring dan Evaluasi Program Pemberdayaan

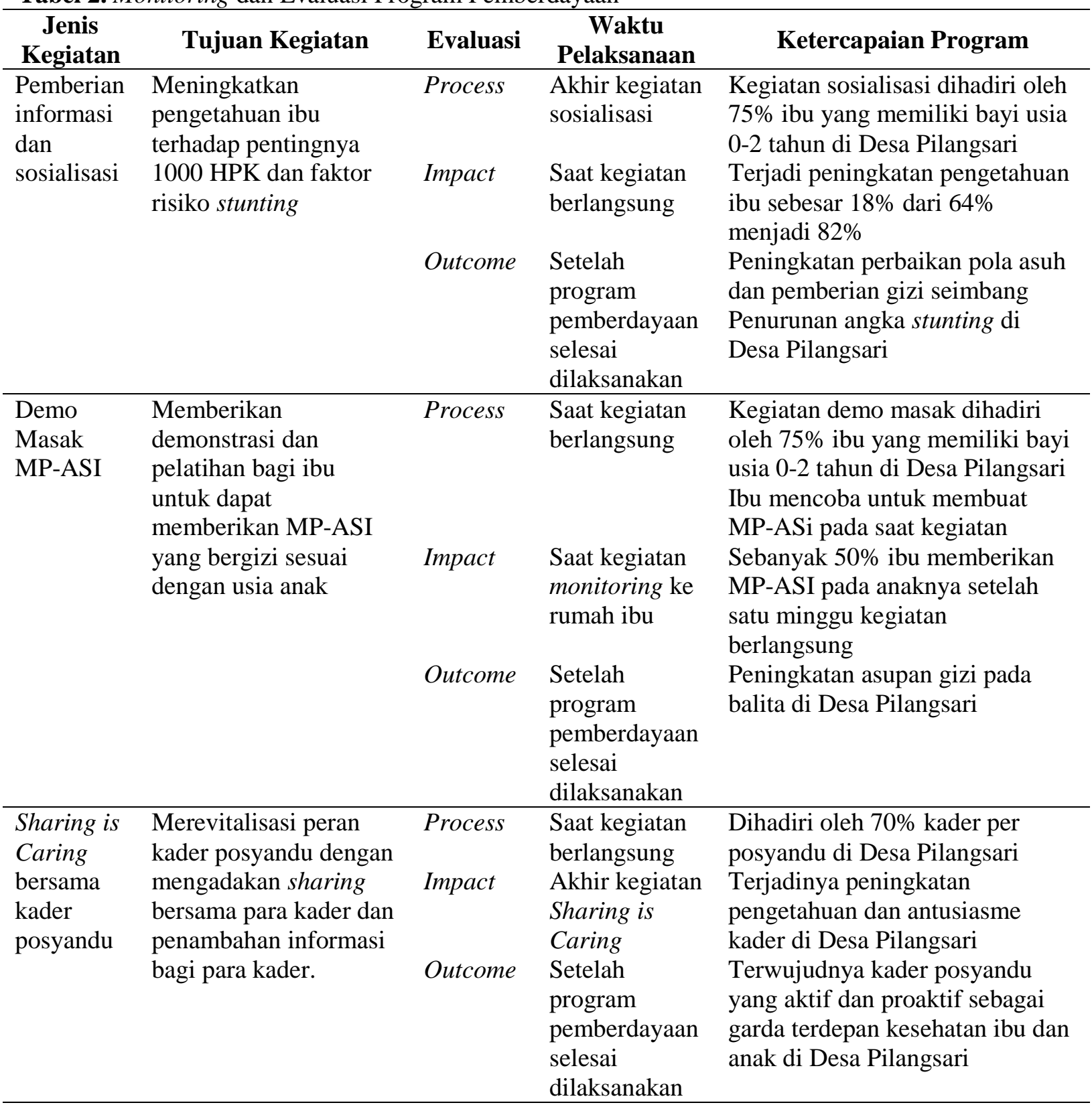

Hasil need assessment diketahui bahwa prioritas masalah yang dihadapi oleh subyek pemberdayaan berfokus pada rendahnya pengetahuan dan program terkait kesehatan ibu dan anak yang didukung dengan pola asuh, lingkungan dan pemberian gizi yang tidak seimbang. Dampak yang diperoleh akibat masalah yang dihadapi adalah tingginya angka stunting pada balita di Desa Pilangsari. Untuk itu perlu dilakukan tindakan intervensi guna meningkatkan pengetahuan ibu dalam memberikan pola asuh yang baik, pemberian makanan yang bergizi untuk mencegah stunting dan merevitalisasi peran kader sebagai garda terdepan kesehatan ibu dan anak di Desa Pilangsari.

\section{Pemberdayaan Ibu dan Kader (Phase 6)}

Intervensi kegiatan berfokus pemberian informasi dan pelatihan bagi ibu juga diadakan pembekalan bagi kader posyandu dan pengaktifan kembali kegiatan posyandu yang mati suri, yaitu pengukuran tinggi badan dan berat badan anak secara berkala, kegiatan pemberian informasi terkait kesehatan ibu dan anak serta pelaksanaan imunisasi rutin. Pada 1 bulan pelaksanaan kegiatan, kegiatan yang dilakukan antara lain sosialisasi gizi seimbang dan kejadian stunting yang diberikan kepada ibu baduta yang dihadiri oleh perangkat desa, bidan desa, serta ibu baduta, demo masak MP-ASI, program tambahan berupa senam pagi untuk meningkatkan aktivitas fisik ibu, serta program 
revitalisasi kader posyandu dengan mengadakan sharing bersama para kader dan penambahan informasi bagi para kader.

Hasil dari sosialisasi kepada ibu baduta menunjukkan adanya peningkatan pengetahuan mengenai pemberian makanan bergizi dan kejadian stunting pada balita. Analisis perbandingan uji pre-test sebelum pelaksanaan sosialisasi dan post-test setelah pelaksanaan sosialisasi menggunakan uji Wilcoxon signed rank test signifikansi peningkatan pengetahuan ibu adalah $0,005(\mathrm{p}<0,05)$ dengan tingkat keprecayaan $\alpha=0,05$ yang berarti terdapat perbedaan yang bermakna antara pengetahuan ibu saat dilaksanakan pre-test dan post-test.

Materi pertanyaan pre-test dan post-test merupakan gabungan dari pemberian gizi seimbang, pengetahuan terkait stunting dan 1000 Hari Pertama Kehidupan. Berdasarkan hasil perbandingan pre-test dan post-test dapat dilihat terjadi peningkatan sebesar $18 \%$ yaitu pre-test hasil sebesar $64 \%$ mengalami peningkatan pada hasil post-test sebesar $84 \%$.

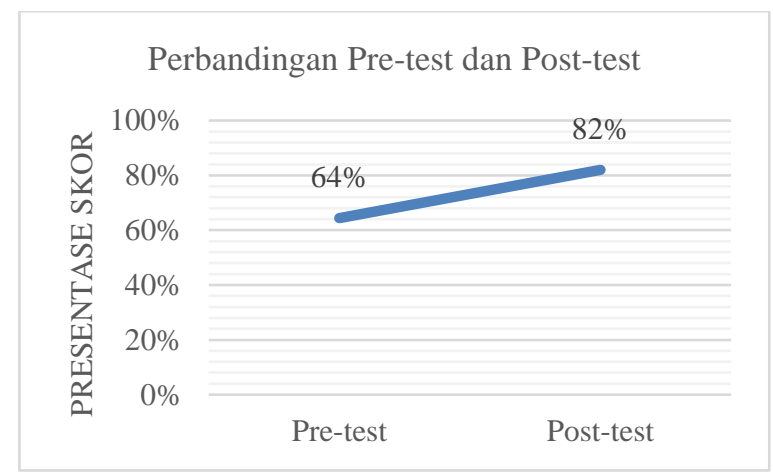

Gambar 2. Grafik Peningkatan Pengetahuan Ibu

\section{Monitoring dan Evaluasi (Phase 7-9)}

Berdasarkan kegiatan yang direncanakan disusun rencana monitoring dan evaluasi untuk melihat seberapa jauh tingkat keberhasilan program dan kesesuaian dengan tujuan yang telah ditetapkan. Penyusunan rencana monitoring dan evaluasi ini mengikuti kerangka PROCEED yang mencakup phase 7-9 (process evaluation, impact evaluation, dan outcome evaluation) Rencana monitoring dan evaluasi mencakup jenis kegiatan dan tujuan kegiatan, waktu pelaksanaan, serta ketercapaian program yang telah dilaksanakan.

\section{Pembahasan}

\section{Need Assesstment}

Grafik pada hasil menunjukkan gambaran hasil need assessmet melalui kerangka PRECEED (phase 1-phase 5). Need assessment dilaksanakan untuk menilai kualitas hidup dan permasalahan yang terjadi sebagai dasar penentuan prioritas program. Berikut adalah pembahasan hasil need assessment berdasarkan kerangka PRECEED :

a. Social Assessment (Phase 1)

Social assessment berhubungan dengan keadaan sosial yang mengindikasikan masalah kesehatan yang dapat mempengaruhi kualitas hidup. Hubungan sehat dan kualitas hidup merupakan hubungan sebab akibat. Input berupa pendidikan, kebijakan, angka pengangguran, kepadatan hunian menyebabkan perubahan outcome, yaitu kualitas hidup. Fase ini membantu masyarakat menilai kualitas hidupya tidak hanya pada fase kesehatan. Berdasarkan hasil analisis, $67 \%$ pendapatan orangtua baduta berada dibawah UMR Kabupaten Bojonegoro. Tingkat ekonomi yang rendah berpengaruh terhadap pemberian asupan makanan anak (Lailatul and Ni'mah., 2015). Penelitian yang dilakukan di negara yang berpendapatan menengah dan rendah menunjukkan bahwa anak-anak yang tinggal di daerah kumuh, semakin bertambahnya usia anak memperburuk risiko untuk stunting (Kyu \& Shannon, 2013). Mayoritas orangtua juga merupakan petani dan buruh tani yang tidak memiliki hari libur, sehingga waktu yang digunakan untuk mengikuti berbagai program kesehatan dan puskesmas tidak banyak Hal ini disebabkan orangtua balita sibuk mengatur rumah tangga dan meluangkan waktunya untuk bekerja guna memenuhi kebutuhan keluarga.

b. Epidemiological Assessment (Phase 2)

Pada diagnosis epidemiologi, dapat diidentifikasi masalah kesehatan yang muncul adalah sebanyak $48 \%$ balita dari 3 dari 4 posyandu di Desa Pilangsari terindikasi stunting. Pengambilan data dilakukan berdasarkan hasil screening balita bulan Agustus di 3 dari 4 posyandu disebabkan data dari 1 posyandu tidak ada pada register posyandu. Sedangkan data Oktober-Desember 2019 belum ada di buku register posyandu. Penentuan kriteria stunting diperoleh berdasarkan Keputusan Menteri Kesehatan RI No. 1995 Tahun 2010 yang diolah oleh peneliti. Masalah stunting merupakan salah satu prioritas masalah kesehatan karena berhubungan dengan meningkatnya risiko terjadinya kesakitan dan kematian, perkembangan otak suboptimal sehingga perkembangan motorik terlambat dan terhambatnya pertumbuhan mental. (Mitra, 2015). 
Stunting merupakan bentuk kegagalan pertumbuhan (growth faltering) akibat akumulasi ketidakcukupan nutrisi yang berlansung lama mulai dari kehamilan sampai usia 24 bulan (Hoffman et al, 2000; Bloem et al, 2013 dalam Mustika and Syamsul, 2018). Penyebab langsung adalah kurangnya asupan makanan dan adanya penyakit infeksi (Unicef, 1990; Hoffman, 2000; Umeta, 2003). Faktor lainnya adalah pengetahuan ibu yang kurang, pola asuh yang salah, sanitasi dan hygiene yang buruk dan rendahnya pelayanan kesehatan (Unicef, 1990). Selain itu masyarakat belum menyadari anak pendek merupakan suatu masalah, karena anak pendek di masyarakat terlihat sebagai anak-anak dengan aktivitas yang normal, tidak seperti anak kurus yang harus segera ditanggulangi. Demikian pula halnya gizi ibu waktu hamil, masyarakat belum menyadari pentingnya gizi selama kehamilan berkontribusi terhadap keadaan gizi bayi yang akan dilahirkannya kelak (Unicef Indonesia, 2013).

\section{c. Behavioral and Environmental Assessment (Phase 3)}

Faktor perilaku : Sebanyak $80 \%$ anggota keluarga baduta di Desa Pilangsari merupakan perokok aktif. Pusat Kajian Jaminan Sosial Universitas Indonesia (2018) yang dikutip oleh website resmi Kementrian Kesehatan menyatakan bahwa konsumsi rokok pada orangtua mengakibatkan anak stunting. Kejadian ini paling banyak ditemui di keluarga miskin. Perilaku merokok berpengaruh pada anak stunting melalui dua cara. Yang pertama, asap rokok memberikan efek langsung pada tumbuh kembang anak dan menganggu penyerapan gizi pada anak. Pengaruh yang kedua, biaya belanja rokok akan mengurangi jatah belanja makanan bergizi, biaya kesehatan, pendidikan, dan lain sebagainya. Pada rumah tangga dengan ayah yang merokok, pengeluaran untuk protein hewani, buah dan sayur, beras, makanan ringan dan makanan bayi, gula dan minyak, dan mie goreng lebih rendah dibandingkan dengan ayah yang tidak merokok (Sari, 2017). Berbagai penelitian juga menyatakan adanya kemungkinan konsumsi rokok orangtua terhadap kejadian stunting, meski belum banyak dikaji lebih jauh.

Selain itu faktor pemberian makanan yang tidak bervariasi juga menjadi faktor perilaku utama terjadinya stunting pada anak. Mayoritas ibu balita memberikan MP-ASI berupa pisang sebagai tambahan ASI atau susu formula dan lauk nabati seperti tahu dan tempe. Pemberian lauk hewani jarang diberikan kepada anak. Selain itu jenis lauk yang diberikan kepada anak tidak bervariasi diakibatkan lokasi desa jauh dengan pasar $(5 \mathrm{~km})$ dan akses menuju pasar sulit untuk dicapai. Sehingga gizi yang diberikan mayoritas berasal dari tanaman yang ditanam di sekitar rumah dan sawah.

Faktor lingkungan : Faktor lingkungan di Desa Pilangsari menjadi salah satu faktor utama resiko kejadian stunting. Hal ini disebabkan berdasarkan hasil observasi sebagian besar tempat tinggal balita belum memenuhi syarat rumah sehat, tidak adanya sistem pengelolaan sampah di desa, ventilasi dan pencahayaan yang kurang, beberapa rumah masih belum memiliki jamban, serta dinding dan lantai belum permanen. Ketersediaan air bersih juga diperoleh warga dari sumur dan sungai Bengawan Solo. Karena lokasi desa yang berada di bantaran sungai menyebabkan Desa Pilangsari ditetapkan sebagai salah satu kawasan KLB demam berdarah dan chikungunya oleh Dinas Kesehatan Kabupaten Bojonegoro.

\section{d. Educational and Behavioral Assessment (Phase 4)}

Predisposing factors : merupakan faktor penguat yang berasal internal individu yang dapat memotivasi perilaku. Faktor ini terwujud dalam pengetahuan, sikap, kepercayaan, nilainilai, dan sebagainya. Pada karakterisitik ibu balita di Desa Pilangsari, mayoritas ibu berpendidikan SD yaitu sebanyak 45\% dan SMP sebanyak 33\%. Tingkat pendidikan seseorang akan mempengaruhi tingkat penerimaan informasi. Semakin tinggi tingkat pendidikan seseorang maka informasi akan lebih mudah diterima. Informasi itu adalah bekal bagi ibu untuk mengasuh anaknya. Beberapa penelitian telah menunjukkan hubungan yang bermakna antara tingkat pendidikan ibu dengan kejadian stunting. (Aini, Elsa Nur., Nugraheni, Sri Achadi., Pradigdo, 2018)

Reinforcing factors : merupakan faktor pendorong masyarakat berupa karakteristik lingkungan yang memfasilitasi tindakan sumber daya dalam mencapai perilaku tertentu. Termasuk program-program, layanan, ketersidaan dan aksesibilitas sumber daya. Faktor yang mendorong kejadian stunting di Desa Pilangsari adalah lokasi desa yang jauh dari Puskesmas Pungpungan (7-8 km) dari desa, selain itu juga akses menuju desa tidak mudah untuk ditempuh dan antar dusun dipisahkan oleh bantaran Sungai Bengawan Solo. Didukung dengan hasil dari indepth-interview kepada 
kader posyandu dan bidan bahwa kegiatan posyandu yang tidak berjalan maksimal disebabkan lokasi desa yang terpisah bantaran sungai, ibu yang pasif, serta bidan yang hanya datang 1-2 kali dalam seminggu. Sebanyak $62 \%$ ibu menyatakan bahwa sumber informasi kesehatan utama mereka berasal dari kader posyandu hal ini menyebabkan informasi yang diperoleh oleh ibu tidak maksimal.

Enabling factors : merupakan faktor yang memfasilitasi perilaku atau tindakan. Enabling factor yang memungkinkan tingginya kejadian stunting di Desa Pilangsari adalah kurangnya sarana dan prasarana pendukung, yaitu bidan desa hanya datang 1-2 kali dalam seminggu di Puskesmas Pembantu untuk melakukan pemeriksaan kesehatan, menimbang bayi, dsb. Hal ini menyebabkan kurangnya informasi yang dapat diperoleh ibu melalui pelayanan kesehatan Puskesmas Pembantu.

\section{e. Administrative and Policy Assessment (Phase 5)}

Pada fase ini dilakukan analisis terkait kebijakan, sumberdaya dan kejadian dalam organisasi yang dapat mendukung atau menghambat perkembangan promosi kesehatan. Berdasarkan metode yang telah dilakukan, dapat diketahui bahwa program kesehatan bagi ibu dari puskesmas sangat terbatas dari sisi sumberdaya. Hanya ada satu bidan yang bertugas di Desa Pilangsari selama 1-2 minggu sekali, bidan desa juga tidak tersedia 24 jam karena rumah bidan berada pada desa yang berbeda. Bidan tidak hanya bertugas pada posyandu dan kesehatan ibu dan anak, tetapi juga melakukan pengecekan kesehatan, posyandu lansia, dan program promosi kesehatan lainnya seperti pengecekan jentik, dan lain sebagainya. Hal ini diperkuat dengan kurangnya dukungan dari stakeholder terkait program kesehatan ibu dan anak di Desa Pilangsari.

\section{Pemberdayaan Ibu dan Kader (Phase 6)}

Selama 20 tahun terakhir, penanganan masalah stunting sangat lambat. Secara global, persentase anak-anak yang terhambat pertumbuhannya menurun hanya 0,6 persen per tahun sejak tahun 1990. Diprediksi, jika hal tersebut berlangsung terus, maka 15 tahun kemudian, diperkirakan 450 juta anak-anak mengalami keterlambatan pertumbuhan (stunting) (Cobham et al, 2013). Penanganan stunting membutuhkan keterlibatan dari berbagai sektor, mengingat faktor determinan stunting juga bermacam-macam. Peran orangtua menjadi peran yang paling utama dalam penanganan stunting karena pola asuh orangtua, pemberian gizi, pemberian ASI ekslusif, tingkat pengetahuan dan pendidikan orangtua sangat berpengaruh terhadap kejadian stunting pada anak. Selain itu juga peran tenaga kesehatan, puskesmas dan kader posyandu sebagai garda utama kesehatan ibu dan anak sangat berperan penting dalam memberikan edukasi, bimbingan, imunisasi, pengukuran tinggi dan berat badan, dan sebagainya.

Dalam pelaksanaan program pemberantasan stunting, fokus utama kegiatan dipusatkan kepada ibu balita dan kader posyandu yang langsung berkaitan dengan anak melalui berbagai kegiatan yang mendukung intervensi spesifik, yaitu tindakan atau kegiatan yang dalam perencanaannya ditujukan khusus untuk kelompok 1000 hari pertama kehidupan (HPK) dan bersifat jangka pendek. Kegiatan ini pada umumnya dilakukan pada sektor kesehatan, seperti imunisasi, PMT ibu hamil dan balita, monitoring pertumbuhan balita di Posyandu, suplemen tablet besi-folat ibu hamil, promosi ASI Eksklusif, MP-ASI, dan sebagainya. (Republik Indonesia, 2012).

Program pemberdayaan ini berusaha mewujudkan ibu yang memiliki pengetahuan dan kesadaran yang tinggi serta merevitalisasi kader dan layanan posyandu untuk menurunkan prevalensi stunting pada balita di Desa Pilangsari. Ibu bayi usia 0-2 tahun dipilih sebagai subyek pemberdayaan dikarenakan pertumbuhan anak yang baik pada 1000 Hari Pertama Kehidupan merupakan bekal yang baik untuk meningkatkan pertumbuhan anak dan mencegah kejadian stunting. Pemberdayaan kader dikembangkan berdasarkan fakta di lapangan kurangnya keterlibatan stakeholder dan minimnya sumber daya yang dimiliki oleh puskesmas. Kader merupakan masyarakat internal yang ada di Desa Pilangsari sehingga kader memiliki pengertian yang lebih mendalam terkait kondisi dari ibu dan balita yang ada di Desa Pilangsari serta diharapkan proses penyampaian komunikasi, informasi dan edukasi kepada ibu balita tepat metode dan tepat sasaran. Revitalisasi dan pemberdayaan kader posyandu dapat menjadi solusi yang baik bagi penanganan stunting, diharapkan kader yang aktif akan membentuk ibu balita yang aktif dan peka terhadap kebutuhan kesehatan. 


\section{Monitoring dan Evaluasi (Phase 7-9)}

Pelaksanaan monitoring dan evaluasi disesuaikan dengan kerangka PROCEED pada phase 7-9 yang mencakup evaluasi process, impact, dan outcome. Berdasarkan tabel rincian monitoring dan evaluasi program hampir semua indikator keberhasilan telah tercapai. Hal ini, menunjukkan bahwa program intervensi yang telah dilakukan telah efektif dan sesuai dengan kondisi sasaran. Namun, pelaksanaan monitoring dan evaluasi di tahap outcome masih belum mencapai indikator yang ditentukan karena proses monitoring dan evaluasi outcome sendiri dilakukan dengan jangka waktu yang panjang setelah pelaksanaan program dan pengukuran sudah tidak memungkinkan untuk dilaksanakan. Sehingga evaluasi outcome dalam tabel monitoring dan evaluasi tidak dapat diukur ketercapaiannya.

\section{KESIMPULAN DAN SARAN}

\section{Kesimpulan}

Program pemberdayaan kader posyandu dan ibu balita di Desa Pilangsari merupakan program yang bertujuan untuk mencegah stunting di Desa Pilangsari, melibatkan kader posyandu dan ibu sebagai subyek utama, program ini mengacu pada PRECEDE-PROCEED sebagai framework pengembangan program pendidikan kesehatan. Berdasarkan hasil analisis melalui kerangka PRECEDE diperoleh faktor determinan stunting yang menjadi perhatian utama adalah perilaku keluarga, pengetahuan dan pola asuh orangtua yang diakibatkan kurangnya sumber informasi dan kegiatan posyandu yang tidak berjalan maksimal. Program ini terbukti mampu meningkatkan pengetahuan ibu balita tentang pentingnya $1000 \mathrm{HPK}$, pemberian MP-ASI bagi anak dan faktor risiko kejadian stunting, serta meningkatkan keaktifan kader posyandu di Desa Pilangsari.

\section{Saran}

Penelitian yang menggunakan metode serupa perlu untuk mengukur outcome dari program yang telah dilaksanakan pada jangka waktu panjang. Selain itu Dinas Kesehatan dan puskesmas perlu untuk menindaklanjuti lebih jauh terkait kasus stunting, pengelolaan sampah dan rumah sehat di wilayah Desa Pilangsari. Upaya yang dilakukan ini diharapkan mampu mengurangi kasus stunting dan memberikan kaulitas hidup yang baik bagi balita di Desa Pilangsari.

\section{DAFTAR RUJUKAN}

1] Aini, Elsa Nur., Nugraheni, Sri Achadi., Pradigdo, S. F. 2018 Faktor Yang Mempengaruhi Stunting Pada Balita Usia 24-59 Bulan Di Puskesmas Cepu Kabupaten Blora. Jurnal Kesehatan Masyarakat (e-Journal), 6(5), pp. 454-461.

2] Budiastutik, I. and Rahfiludin, M. Z. 2019. Faktor Risiko Stunting pada anak di Negara Berkembang Risk Factors of Child Stunting in Developing Countries. Amerta Nutrition, pp. 122-126. doi: 10.2473/amnt.v3i3.2019.122-129.

3] Cobham A, Garde M, Crosby L. 2013. Global Stunting Reduction Target: Focus On The Poorest Or Leave Millions Behind, Available at : www.savethechildren.org.uk

4] Departemen Kesehatan Republik Indonesia. 2019. Kebijakan dan Strategi Penanggulangan Stunting di Indonesia. In Germas. Available at : https://www.persi.or.id/images/2019/data/ FINAL_PAPARAN_PERSI_22_FEB_201 9_Ir._Doddy.pdf

5] Departemen Kesehatan Republik Indonesia. 2011. Keputusan Menteri Kesehatan RI tentang Standar Antropometri Penilaian Status Gizi Anak. In Standar Antropometri Penilaian Status Gizi Anak.

6] Departemen Kesehatan Republik Indonesia. 2018. Konsumsi Rokok Akibatkan Anak Stunting. Available at : http://p2ptm.kemkes.go.id/kegiatanp2ptm/pusat-/konsumsi-rokok-akibatkananak-stunting

7] Departemen Kesehatan Republik Indonesia. 2018. Hasil Utama Riskesdas. Available at: https://kesmas.kemkes.go.id/assets/upload/ dir_519d41d8cd98f00/files/Hasilriskesdas-2018_1274.pdf

8] Dinas Kesehatan Kabupaten Bojonegoro. 2019. Perbaiki Gizi dan Kesehatan Masyarakat, Bojonegoro Canangka Program 1000 GPS. Available at : http://www.bojonegorokab.go.id/berita/bac a/4135/Perbaiki-Gizi-dan-KesehatanMasyarakat,--Bojonegoro-CanangkanProgram-1.000-GPS 
9] Green, L dan Kreuter, M. 2005. Health program planning: an educational and ecological approach. 4th edition. New York: McGraw-Hill

10] Hadi, M. I., Kumalasari, M. L. F. and Kusumawati, E. 2019. Faktor Risiko yang Berhubungan dengan Kejadian Stunting di Indonesia: Studi Literatur. Journal of Health Science and Prevention, 3(2), pp. 86-93. doi: 10.29080/jhsp.v3i2.238.

11] Lailatul, M. and Ni'mah., C. 2015. Hubungan Tingkat Pendidikan, Tingkat Pengetahuan dan Pola Asuh Ibu dengan Wasting dan Stunting pada Balita Keluarga Miskin. Media Gizi Indonesia, 10(2015), pp. 84-90. doi: Vol. 10, No. 1 Januari-Juni 2015: hlm. 84-90 terdiri.

12] Kyu HH, Shannon HS, Georgiades K, Boyle MH. 2013. Association of Urban Slum Residency with Infant Mortality and Child Stunting in Low and Middle Income Countries. Hindawi Publishing Corporation BioMed Research International Volume, Article ID 604974, 12 http://dx.doi.org/10.1155/2013/604974 pages

13] Mitra. 2015. Permasalahan Anak Pendek (Stunting) dan Intervensi untuk Mencegah Terjadinya Stunting (Suatu Kejadian Kepustakaan). Jurnal Kesehatan Komunitas, Vol.2, No. 6, Mei 2015

14] Mustika, W. and Syamsul, D. 2018. Analisis Permasalahan Status Gizi Kurang Pada Balita di Puskesmas Teupah Selatan Kabupaten Simeuleu. Jurnal Kesehatan Global, 1(3), p. 127. doi: 10.33085/jkg.v1i3.3952.

15] Nefy, N., Lipoeto, N. I. and Edison, E. 2019. Implementasi Gerakan 1000 Hari Pertama Kehidupan di kabupaten Pasaman 2017 [Implementation of The First 1000 Days of Life Movement in Pasaman Regancy 2017$]</$ br>', Media Gizi Indonesia, 14(2), p. $186 . \quad$ doi: 10.20473/mgi.v14i2.186-196.

16] Republik Indonesia. 2012. Kerangka Kebijakan Gerakan Sadar Gizi dalam rangka Seribu Hari Kehidupan (1000 HPK) versi 5 September 2012. Available at : http://www. kgm.bappenas.go.id
17] Rifiana, A. J. and Agustina, L. 2018. Analisis Kejadian Stunting Pada Balita Di Desa Pasirdoton Kecamatan Cidahu Kabupaten Sukabumi Provinsi Jawa Barat Tahun 2017-2018. Jurnal Akademi Keperawatan Husada Karya Jaya, 4(2), pp. 7869-7884. Available at: http://ejurnal.husadakaryajaya.ac.id/index. php/JAKHKJ/article/view/95.

18] Sari, S. P. 2017. Konsumsif rokok dan tinggi badan orangtua sebagai faktor risiko stunting anak usia 6-24 bulan di perkotaan. Ilmu Gizi Indonesia, 01(Vol 1, No 1 (2017): Agustus), pp. 1-9. Available at: http://ilgi.respati.ac.id/index.php/ilgi2017/a rticle/view/6.

19] Sulistiawan, D., Hakim, L., \& Hargono, R. 2014. Pendidikan Kesehatan Reproduksi Remaja Melalui Pemberdayaan Pendidik Sebaya Di Kawasan Lokalisasi Dolly Kota Surabaya. Jurnal Promkes, 2, 140-147.

20] Syabandini, I. S., Pradigdo Siti F., Suyatno, Pangestuti Dina. 2018. Faktor Risiko Kejadian Stunting Pada Anak Usia 6-24 Bulan di Daerah Nelayan. Jurnal Kesehatan Masyarakat Volume 6

21] Tim Nasional Percepatan Penanggulangan Kemiskinan. 2018. Technical Coordination Meeting for Stunting Prevention. Available at : http://tnp2k.go.id/program/technicalcoordination-meeting-for-stuntingprevention

22] Umeta M, West CE, Verhoef $H$, Haidar J, Hautvast J. (2003).Factors Associated with Stunting in Infants Aged 5-11 Months in the DodotaSire District, Rural Ethiopia. Journal Nutrition. 133: 1064 -1069.

23] Unicef. 1990. Strategy for improved nutrition of children and women in developing countries. New York.

24] Unicef Indonesia. 2013. Ringkasan Kajian Gizi Ibu dan Anak, Oktober 2012. Akses www.unicef.org Tanggal 16 Desember 2013.

25] Wulandari, S. and Kurniawan, R. 2019 'Pengelompokan Kabupaten / Kota Di Jawa Timur Berdasarkan Kasus Stunting Balita Menggunakan Algoritme Fuzzy Particle Swarm Optimization-Fuzzy', Jurnal Statistika, 7(1). 